\title{
ANALISIS STRATEGI COPING TERHADAP STRESS GURU BIOLOGI DI SMA
}

\section{THE ANALYSIS OF COPYING STRATEGY TOWARDS THE STRESS OF BIOLOGY TEACHER IN SMA}

\author{
Sumarni M1), Wahyuni Ismail2), Eka Damayanti ${ }^{3)}$ \\ 1,2,3)Fakultas Tarbiyah dan Keguruan Universitas Islam Negeri Alauddin Makassar \\ sumarnimalik123@gmail.com ${ }^{12}$, wahyuni.ismail@gmail.ac.id ${ }^{2)}$ eka.damayanti@uin-alauddin.ac.id ${ }^{3)}$
}

\begin{abstract}
Abstrak
Penelitian ini bertujuan untuk, mengetahui gambran stres yang dialami oleh guru biologi, mengetahui strategi coping yang dilakukan oleh guru biologi, dan mengetahui jenis coping yang digunakan oleh guru. Penelitian ini menggunakan metode kualitatif dengan teknik pengambilan data wawancara dan observasi. Analisis menggunakan reduksi data, penyajian data dan verifikasi. Pemeriksaan keabsahan data menggunakan triangulasi data dan pengecekan data. Subyek dalam penelitian ini adalah wanita dewasa yang bekerja sebagai guru yang berusia 35 tahun, 45 tahun dan 30 tahun, sebanyak 3 orang, guru yang telah bekerja 5 tahun keatas. Hasil penelitian ini menunjukkan bahwa guru mengalami stres dengan adanya tanda-tanda secara fisiologis, emosional, kognitif, perilaku dan interpersonal. Stress diakibatkan dengan urusan rumah tangga dan kesibukan disekolah. Sedangkan strategi coping yang digunakan adalah problem focused coping dan emotional focused coping. Pada problem focused coping individu cenderung menggunakan seeking social support for instrumental reason dalam menyelesaikan masalah yaitu mencari dukungan keluarga dan orang-orang terdekatnya dengan cara menceritankan masalahnya dan meminta pendapat atau nasehat dari orang tersebut. Kemudian emotional focused coping individu cenderung menggunakan turning to religion yaitu selalu berserah diri kepada Allah SWT. dengan berdoa agar diberi kemudahan dalam menyelesaikan masalah yang dihadapinya, agar diberi kesehatan dan selalu bersyukur atas apa yang telah didapatkannya.
\end{abstract}

Kata Kunci: stress, strategi coping, guru

\begin{abstract}
This study aims to, know the stress imagery experienced by biology teacher, know coping strategies undertaken by biology teachers, and know the type of coping used by the teacher. This research uses qualitative method with interview and observation data. Analysis uses data reduction, data presentation and verification. Verification of data validity using data triangulation and data checking. Subjects in this study were adult women who worked as teachers aged 35 years, 45 years and 30 years, as many as 3 people, teachers who have worked 5 years and above. The results of this study indicate that teachers experience stress with signs physiological, emotional, cognitive, behavioral and interpersonal. Stress is caused by household affairs and busyness in school. While coping strategies used are problem focused coping and emotional focused coping. In problem focused coping, individuals tend to use social support for instrumental reason in solving the problem of seeking the support of their family and their closest people by narrating the problem and asking for opinions or advice from the person. Then emotional focused coping individuals tend to use turning to religion that is always surrendered to Allah SWT. by praying for ease in solving the problems he faces, to be given health and always be grateful for what he has got.
\end{abstract}

Keywords: stress, coping strategy, teacher 
How to Cite: Sumarni, M., Ismail, W., \& Damayanti, E. (2019). Analisis strategi coping terhadap stress guru biologi di SMA. Al-Asma: Journal of Islamic Education, 1(2), 105-114.

\section{PENDAHULUAN}

Guru dalam kamus besar Bahasa Indonesia diartikan sebagai seorang yang pekerjaannya (mata pencahariannya) mengajar. Dalam sebuah sistem pendidikan tugas seorang guru adalah sebagai pengajar. Mengajar merupakan melatihkan ketrampilan, menyampaikan pengetahuan, membentuk sikap dan memindahkan nilainilai. Menurut Syam kata mengajar dapat ditafsirkan bermacam-macam, misalnya: menularkan pengetahuan dan kebudayaan kepada orang lain, melatih ketrampilan jasmani kepada orang lain, menanamkan nilai dan keyakinan kepada orang lain (Syah, 2002).

Pekerjaan mengajar itu sendiri bukan merupakan pekerjaan yang mudah karena dibutuhkan suatu ketrampilan khusus. Mengajar yaitu pekerjaan yang banyak dan tidak ringan, karena guru bukan hanya menyampaikan pelajaran di depan kelas, tetapi juga menyiapkan dan mendesain bahan pelajaran, memberikan tugas-tugas, menilai proses dan hasil belajar murid, merencanakan kegiatan-kegiatan lain, dan menegakkan disiplin . (Mahmud, 1990).

Guru merupakan pendidik profesional dengan tugas utama mendidik, mengajar, membimbing, mengarahkan, melatih, menilai, dan mengevaluasi peserta didik pada pendidikan anak usia dini melalui jalur pendidikan formal, pendidikan dasar, dan pendidikan menengah. Dalam sebuah sistem pendidikan tugas seorang guru adalah sebagai pengajar. Mengajar yaitu melatihkan ketrampilan, menyampaikan pengetahuan, membentuk sikap dan memindahkan nilai-nilai (Syam, 2002). Semua komponen tersebut tidak dapat tercapai jika seorang guru berada dalam kondisi tertekan. Kondisi yang tertekan ini sering dikenal dengan stress (Wilonoyudho, 2001).

Stress merupakan suatu bentuk tanggapan seseorang, baik secara fisik maupun mental, terhadap suatu perubahan di lingkungannya yang dirasakan mengganggu dan mengakibatkan dirinya terancam (Anoraga, 2006). Stress pada diri seseorang dapat menimbulkan berbagai macam gangguan baik bagi dirinya sendiri, orang lain maupun bagi lingkungan kerjanya. Hubungan sebab akibat antara stress dengan penyakit seperti jantung, gangguan pencernaan, darah tinggi, maag, alergi, dan beberapa penyakit lainnya. Stress yang dialami oleh seseorang akan merubah sistem kekebalan tubuh dan menurunkan daya tahan tubuh terhadap serangan penyakit (Rini, 2002).

Seorang guru yang tidak mampu melakukan coping terhadap kondisi stressnya akan bertidak secara tidak wajar terutama kepada murid yang tidak melaksanakan tugas dengan baik atau kepada murid yang bertingkah laku tidak baik. Coping stress merupakan suatu proses dimana individu mencoba untuk mengelola jarak yang ada antara tuntutan (baik itu tuntutan yang berasal dari individu maupun tuntutan yang berasal dari lingkungan) dengan sumber-sumber daya yang mereka gunakan dalam menghadapi situasi stress full (Smet, 1994). Kata mengelola dalam definisi ini penting yakni menunjukkan bahwa upaya mengatasi masalah cukup bervariasi dan tidak selalu mengarah pada solusi dari masalah itu sendiri. 
Berdasarkan observasi awal yang dilakukan oleh peneliti pada hari rabu, 02 Agustus 2017 di sekolah SMA di Jeneponto. Hasil wawancara menunjukkan bahwa guru sangat sulit menghadapi kondisi yang tertekan akibat tingkah laku beberapa murid yang sulit diatur. Jika dinasihati, murid tersebut tidak pernah mendengarkan. Jika murid sudah sangat keterlaluan sampai mengganggu temannya yang lain, guru semakin bingung bagaimana harus menasehati. Apalagi terjadi perkelahian antara teman sekelasnya pada saat pemberian materi sehingga guru merasa kesal tidak dianggap sedang berada didepan kelas. Sehingga hanya memperbanyak sabar saat menghadapi murid. Masalah lain yang juga membuat guru untuk sulit menghadapinya adalah wali murid yang selalu menyalahkan pihak sekolah khususnya guru jika anak mereka mengalami masalah, seperti mengeluarkan kata-kata kotor. Pada hal pihak sekolah berusaha semaksimal mungkin yang terbaik untuk anak didik mereka.

Selanjutnya obbservasi kedua yang dilakukan oleh peneliti pada hari kamis, 03 agustus 2017 di sekolah SMA Negeri 5 Jeneponto. Hasil wawancara yang dilakukan pada seorang guru, menyatakan bahwa beliau sangat sedih ketika berhadapan dengan wali murid yang ikut mendikte tentang cara mengajar anaknya. Apa lagi orang tua murid menuntut anaknya dapat nilai yang bagus, sehingga guru merasa tertekan mengingat sebagian muridnya sangat sulit diatur dan banyak bermain dikelas pada saat berlangsung proses belajar mengajar. Sulitnya melakukan coping terhadap kondisi yang stress ini mengakibatkan guru susah untuk berkonsentrasi dalam melakukan pekerjaan serta masalah ini menjadi sebuah beban fikiran yang mengakibatkan sulit untuk tidur.

Masalah yang dihadapi guru tersebut akan menyebabkan timbulnya stress. Stress timbul karena adanya stimulus baik yang datang dari faktor internal maupun eksternal. Stimulus-stimulus ini yang disebut sebagai stressor yang dapat mempengaruhi batas kemampuan coping seseorang. Coping adalah proses di mana seseorang berusaha untuk mengelola tuntutan yang menekan tersebut disebut sebagai coping. Tentunya, untuk meminimalkan atau menghilangkan stressor yang ditimbulkan dari berbagai masalah yang dihadapi, para guru membutuhkan perilaku coping yang sesuai, sehingga mereka akan dapat berfungsi dengan baik sebagai individu maupun sebagai pendidik atau pengajar dengan tugasnya masing-masing. Berdasarkan uraian sebelumnya dan pengamatan di lapangan, penulis mengadakan penelitian dengan judul "Analisis Strategi Coping Terhadap Stress Guru Biologi Di SMA Negeri 5 Jeneponto".

\section{METODE PENELITIAN}

Jenis penelitian ini merupakan penelitian kualitatif yang bermaksud untuk memahami fenomena tentang yang dialami oleh subyek penelitian dalam hal perilaku, persepsi, motivasi, tindakan dan lain-lain. Disebut penelitian kualitatif, karena sumber data utama penelitian ini adalah berupa kata-kata dan tindakan dari orang-orang yang diamati atau diwawancarai. Jenis penelitian ini merupakan jenis penelitian studi kasus.

Penelitian ini berfokus pada strategi coping terhadap stress guru. Strategi coping ini dipahami sebagai segala usaha individu untuk mengatur tuntutan lingkungan dan konflik yang muncul, mengurangi ketidak sesuaian/kesenjangan persepsi antara tuntutan situasi yang menekan dengan kemampuan individu dalam memehami tuntutan tersebut. Penelitian ini berlokasi di SMA Negeri 5 Jeneponto. Desa Bodo Baji, Kecamatan Batang, Kabupaten Jeneponto. 
Subyek dalam penelitian ini berjumlah tiga orang guru Biologi di sekolah SMA Negeri 5 Jeneponto. Subjek telah memenuhi purposivitas dengan karakteristik 1) seorang guru biologi; 2) minimal mengajar disekolah selama 5 tahun; 3) pernah menangani siswa yang bermasalah; 4) sudah berumah tangga.

Pengumpulan data dilakukan dengan observasi, wawancara, dan dokumentasi yaitu, Jenis observasi yang digunakan pada penelitian ini, yaitu observasi non partisipasi (non participan observation) yakni peneliti bagian luar dari situasi sosial, dan dia hanya memasuki sosial saat membutuhkan informasi dan data penelitian. Dalam penelitian ini, peneliti menggunakan catatan yang terdapat pada lampiran yang merupakan catatan tulisan mengenai apa yang didengar, dilihat, dialami dan dipikirkan dalam proses pengumpulan data dan merupakan refleksi terhadap data penelitian.

Jenis wawancara yang digunakan wawancara semistruktur. Wawancara ini sudah termasuk dalam kategori in-depth interview yang merupakan wawancara mendalam dilakukan berkali-kali dan membutuhkan waktu yang lama bersama informan dilokasi penelitian. Dimana dalam pelaksanaannya lebih bebas apabila dibandingkan dengan wawancara terstruktur. Tujuan dari wawancara ini adalah untuk menemukan permasalahan secara lebih terbuka, di mana pihak yang diajak wawancara diminta pendapat. Dalam melaksanakan wawancara, peneliti perlu mendengarkan secara teliti dan mencatat apa yang dikemukakan oleh informan". Dalam hal ini responden yang dipilih adalah para guru biologi karena mereka dianggap memiliki pengetahuan dan mendalami situasi serta lebih mengetahui informasi yang diperlukan.

Dokumentasi yaitu pengumpulan data dengan jalan mencatat atau mengambil dokumen-dokumen yang berkaitan dengan masalah yang dibahas selain itu dengan melakukan pencatatan data-data yang dibutuhkan pada format yang digunakan peneliti dapat memudahkan pengembangan materi yang terkait pada pembahasan skripsi ini. Dokumentasi yang dilakukan ini untuk mendukung hasil dari observasi dan wawncara yang dilakukan sebelumnya.

Instrumen penelitian berkaitan dengan kegiatan pengumpulan data dan pengolahan data, tentang variabel-variabel yang diteliti. Sesuai dengan jenis penelitian yang dilaksanakan (kualitatif deskriptif), peneliti menggunakan jenis instrumen penelitian berupa pedoman wawancara. Peneliti mengadakan proses tanya jawab atau wawancara dengan informan yang dianggap perlu untuk diambil keterangannya mengenai masalah yang akan dibahas. Teknik pengelolahan data dalam penelitian kualitatif secara umum dimulai sejak pengumpulan data, reduksi data, penyajian data, dan penarikan kesimpulan atau verifikasi.

Berdasarkan data kualitatif yang diperoleh, teknik analisis data yang digunakan adalah deskriptif teknik yang menggambarkan data dengan kata-kata atau kalimat yang dipisah-pisahkan menurut kategori untuk memperoleh kesimpulan. Pada pelaksanaannya, analisis data bersifat terbuka. Dikatakan terbuka karena terbuka bagi perubahan, perbaikan dan penyempurnaan berdasarkan data yang baru masuk.

Untuk menguji keabsahan data yang telah dikumpulkan, peneliti menggunakan tiga teknik pemeriksaan Triangulasi. Pemeriksaan keabsahan data yang memanfaatkan sesuatu yang lain di luar data untuk keperluan pengecekan atau sebagai pembanding terhadap data tersebut. Triangulasi dalam penguji kreabiliditas ini diartikan sebagai data dari berbagai sumber, dengan cara, dan berbagai waktu. Dengan demikian terdapat 
triangulasi sumber, teknik dan waktu (Sugiyono, 2014). Peneliti memilih triangulasi sumber dimana Triangulasi ini juga disebut sebagai teknik penguji yang memanfaatkan penggunaan sumber yaitu membandingkan dan mengecek terhadap data yang diperoleh dengan cara membandingkan apa yang dikatakan orang di depan umum dengan apa yang dikatakan secara pribadi, membandingkan hasil wawancara dengan isi suatu dokumen yang saling berkaitan, mengadakan pembicaraan dengan banyak pihak untuk mencapai pemahaman tentang suatu atau berbagai hal (Yanti, 2013). Teknik pemeriksaan triangulasi, dimaksudkan agar peneliti dapat mengecek keabsahan data sebagai perbandingan dengan terhadap data yang lain.

\section{HASIL DAN PEBAHASAN}

\section{Subyek Penelitian I (NA)}

NA adalah seorang guru biologi yang berusia 35 tahun, telah mengabdi sebagai guru selama 12 tahun, dengan penghasilan Rp. 3. 3000.000,00 per bulan. Ibu NA memiliki anak yang berjumlah 3 orang. Memiliki hungungan baik dengan keluarganya. Selama menjadi guru ibu NA tidak pernah mengikuti kursus apapun.

ibu NA pernah beberapa kali mengalami stress dikarenakan tuntutan dari ibu rumah tangga maupun sebagai seorang guru. Sebagai ibu rumah tangga, hal yang membuat ibu stress yaitu mendidik anak, karena anak banyak maunya dan harus hati-hati dalam mendidik karena akan berpengaruh pada perkembangannya, dan sebagai guru yaitu pada saat mengajar di kelas siswa ribut di belakang kelas. Adapun gambaran umum strategi coping NA dapat diuraikan dari tiap aspek resiliensi sebagai berikut:

a) Problem focus coping (PFC)

Ibu NA selalu berpikir positif bahwa masalah atau stres yang dialaminya seiring berjalannya waktu akan terselesaikan sendiri. Tetapi jika dirasa memberatkan ibu NA mencoba untuk memperoleh dukungan dari orang terdekatnya dengan cara menceritakan permasalahannya atau mencari hiburan berupa membuka internet.

\section{b) Emositional Focus Coping (EFC)}

Disaat mengalami stres atau mendapatkan sebuah masalah yang dirasa tidak memberatkan, ibu NA hanya mendiamkan sejenak dan membiarkan masalah tersebut, yang kemudian akan dicari penyelesaiannya. Ibu NA juga selalu berdoa kepa Allah SWT. disaaat mendapatakan masalah maupun tidak dan meminta agar selalu diberi kesehatan dan selalu bersyukur.

\section{Subyek Penelitian II (RM)}

Ibu RM adalah seorang guru biologi sekaligus ibu rumah tangga yang berusia 45 tahun, telah mengabdikan dirinya sebagai guru selam 17 tahun, dengan penghasilan Rp. 4.000.000,00 per bulan. Ibu RM juga memiliki sebuah toko tabung gas yang dikelolahnya dengan penghasilan \pm 3 juta perbulan. Ibu RM memiliki anak yang berjumlah 3 orang. Beliau Memiliki hubungan baik dengan keluarganya. Selama menjadi guru, ibu RM pernah mengikuti kursus komputer beberapa kali dikarenakan belum terlalu lancar dalam mengoperasikan komputer, selama menjadi guru, ibu RM sering mengalami stres diakibatkan suaminya sendiri yaitu disaat ibu RM sedang mengajar dikelas biasa tiba- tiba sang suami menelpon dan menyuruhnya pulang, dikarenakan sang suami bisa memiliki tamu yang datang hampir tiap hari dan harus dijamu. Belum lagi materi yang diajarkannya belum selesai dikerenakan harus pulang ke rumah. 
Adapun gambaran umum strategi coping NA dapat diuraikan dari tiap aspek resiliensi sebagai berikut:

a) Problem focus coping (PFC)

Disaat mengalami stres atau mendapatkan sebuah masalah ibu RM menghadapinya dengan memahami setiap masalahnyan dan memikirkan jalan keluar dari maasalah atau stres tersebut. Seperti saat siswanya mendapatkan nilai yang tidak memenuhi strandar ibu RM akan memberikan tugas tambahan kepada siswanya untuk memperbaiki nilai tersebut. Saat ibu RM kesulitan dalam membagi waktu saat mengajar dan menjamu tamu disaat ada tamu dirumah. Ibu RM akan menceritakan masalahnya kepada keluarga atau pun rekan-rekan kerjanya untuk memperoleh solusi, informasi atau pun dukungan dalam menyelesaikan masalahnya.

\section{b) Emotional Focus Coping (EFC)}

Ibu RM pernah menegur suaminya tentang teman-temannya jika kerumahnya tetapi teguran tersebut hanya diabaikan saja oleh suaminya, bukannya ibu RM tidak suka jika teman suaminya datang bertamu tetapi ibu RM hanya meminta pengertiannya saja dan tidak diganggu saat mengajar. Disaat mengalami stress atau mendapatkan masalah ibu RM selalu beribadah dan berdoa kepada Allah SWT. agar diberi kesehatan, rezeki dan meminta kemudahan agar masalah yang dihadapinya selalu diberi kemudahan. Ibu RM juga selalu bersyukur dengan atas apa yang telah didapatkannya.

\section{Subyek Penelitian III (SF)}

Ibu SF adalah seorang guru biologi sekaligus ibu rumah tangga yang berusia 30 tahun, telah mengabdikan dirinya sebagai guru selama 8 tahun, dengan penghasilan \pm 3 juta per bulan. Memiliki hubungan yang sangat baik dengan keluarganya, ibu SF memiliki anak 2 orang. Selama menjadi guru ibu SF pernah beberapa kali mengalami stress dikarenakan tuntutan dari ibu rumah tangga maupun sebagai seorang guru. Sebagai ibu rumah tangga, hal yang membuat ibu SF stress yaitu mendidik anak, karena perilaku, tipe, kemauan dan sikap anak berbeda-beda, jadi perlu kesabaran dan teknik dalam menghadapi sikap dan kemauan masing-masing anaknya. Sebagai guru yaitu pada saat mengajar di kelas siswa ribut di belakang kelas.

Adapun gambaran umum strategi coping NA dapat diuraikan dari tiap aspek resiliensi sebagai berikut:

a) Problem focused coping (PFC)

Disaat mengalami stres atau mendapatkan sebuah masalah ibu SF menghadapinya dengan menerima masalah yang dihadapi sambil memikirkan jalan keluar permasalahan. Seperti, saat melihat siswanya yang bolos, pertama akan ditegur tetapi jika dilakukuan lebih dari 3 kali maka akan dilaporkan kepihak BK. Disaat mengajar atau melakukan praktikun siswanya ribut, dan jika ditegur siswanya tidak akan medengar. Disaat mengalami stres atau kejenuhan Ibu SF bercerita ke temannya atau rekan-rekan kerjanya untuk memperoleh solusi, informasi atau pun dukungan dalam menyelesaikan masalahnya.

b) Emotional Focused Coping (EFC)

Disaat mengalami stress atau mendapatkan masalah ibu SF selalu beribadah dan berdoa kepada Allah SWT. agar diberi kesehatan, rezeki dan meminta kemudahan agar masalah yang dihadapinya selalu diberi kemudahan. Ibu RM juga selalu bersyukur dengan atas apa yang telah didapatkannya. 
Strategi coping terhadap stres yang dilakukan oleh guru biologi di SMA Negeri 5 Jeneponto dari tiga subyek yaitu:

\section{Subyek penelitian I (ibu NA)}

Subyek I mengalami gejala-gejala sters seperti sakit kepala, mual, pusing, mudah tersinggung, biasa kecewa dengan perilaku siswa, kurang konsentrasi saat mengajar, sering terlambat dating kesekolah, dan biasa acuh terhadap lingkungan sekitar.

Subyek I menggunakan strstegi coping yang pertama yaitu problem focused coping, diantaranya seeking social support for instrumental reason, seperti meminta dukungan dari orang terdekat dengan cara menceritakan permasalahannya atau meminta nasehat guna menyelesaikan masalahnya. Subyek I hanya menggunakan seeking social support for instrumental reason.

Strategi coping yang kedua yaitu emotion focused coping. diantaranya acceptande, seperti saat mengalami stres atau mendapatkan sebuah masalah yang dirasa tidak memberatkan, hanya mendiamkan sejenak dan membiarkan masalah tersebut. Selanjutnya turning religion, yaitu dengan cara selalu mendekatkan diri kepada Tuhan dan selalu bersyukur. Pada strategi coping ini, subyek tidak melakukan seeking social support for emotional reasons, positive reinterprestation, dan denial.

\section{Subyek penelitian II (ibu RM)}

Subyek II mengalami gejala-gejala stress seperti sakit kepala, pusing, mudah kelah, mudah marah dan kesal, mudah tersinggung, kadang terlambat dating kesekolah, tidak suka keributan, dan mengalami stress.

Subyek II menggunakan strategi coping yang pertama yaitu problem focused coping diantaranya yaitu planning, seperti disaat siswanya mendapatkan nilai yang tidak memenuhi strandar subyek II akan memberikan tugas tambahan kepada siswanya untuk memperbaiki nilai tersebut. Kedua yaitu suppression of compering, seperti kesulitan membagi waktu saat mengajar dan menjamu tamu suami saat datang kerumah. Ketiga yaitu seeking social support for instrumental reason. Seperti menceritakan masalahnya kepada keluarga guna menghadapi masalah yang dihadapinya. Subyek II tidak menggunakan active coping, dan restraint coping.

Strategi coping kedua yaitu emotional focused coping, diantaranya seeking social support for emotional, seperti pernah menegur suaminya tentang teman-temannya jika kerumahnya tetapi teguran tersebut hanya diabaikan saja oleh suaminya, bukannya subyek II tidak suka jika teman suaminya datang bertamu tetapi subyek II hanya meminta pengertiannya saja dan tidak diganggu disaat mengajar. Selanjutnya turning religion, yaitu dengan cara selalu mendekatkan diri kepada Tuhan dan selalu bersyukur. Subyek II tidak menggunakan positive reinterprestation, acceptande dan denial.

\section{Subyek penelitian III (SF)}

Subyek III mengalami gejala-gejala stress seperti kelelahan, pegal pada bagian tubuh tertentu, sakit kepala, tidak mudah emosi tapi kadang juga emosi, tidak suka keributan, kadang terlambat datang kesekolah, biasa kesulitan dalam nenertibkan siswa, dan peka terhadap lingkungannya.

Subyek III menggunakan strategi coping, yang pertama yaitu problem focused coping diantaranya yaitu planning, seperti saat melihat siswa yang bolos, pertama akan ditegur tetapi jika dilakukan lebih dari 3 kali maka akan dilaporkan kepihak BK. Selanjutnya seeking social support for instrumental reason, seperti bercerita ke temannya 
atau rekan-rekan kerjanya untuk memperoleh solusi, informasi atau pun dukungan dalam menyelesaikan masalahnya.

Strategi coping yang kedua yaitu emotional focused coping, diantaranya turning religion, seperti selalu beribadah dan berdoa kepada Allah SWT. agar diberi kesehatan, rezeki dan meminta kemudahan agar masalah yang dihadapinya selalu diberi kemudahan. Ibu RM juga selalu bersyukur dengan atas apa yang telah didapatkannya. Subyek III hanya menggunakan turning religion dalam strategi coping yang kedua.

Berdasarkan penelitian ini, peneliti menemukan bahwa strategi coping yang dilakukan individu yaitu problem focused coping dan emotional focused coping. Pada problem focused coping individu cenderung menggunakan seeking social support for instrumental reason dalam menyelesaikan masalahnya yaitu mencari dukungan keluarga maupun orang-orang terdekatnya dengan cara menceritankan masalahnya dan meminta pendapat atau nasehat dari orang tersebut. Kemudian emotional focused coping individu cenderung menggunakan turning to religion yaitu selalu berserah diri kepada Allah SWT. dengan berdoa agar diberi kemudahan dalam menyelesaikan masalah yang dihadapinya, agar diberi kesehatan dan selalu bersyukur atas apa yang telah didapatkannya.

Hasil penelitian diatas sejalan dengan hasil penelitian Noviana yang berjudul "Strategi Coping Terhadap Stres Pada Mahasiswa Tunanetra UIN Sunan Kalijaga Yokyakarta", yaitu menggunakan strategi coping problem Focused coping dan emotional focused coping. Dimana implementasinya yaitu berbicara pada orang lain "curhat" ke teman, keluarga atau seprofesi tentang masalah yang sedang dihadapi, dan mencoba mengumpulkan informasi lebih lebih banyak tentang masalah yang dihadapinya.

Hasil penelitian Beatrix \& Damayanti (2016), yang judul Gambaran Resiliensi Ibu Yang Memiliki Anak Autis Di Taman Pelatih Harapan Makassar mempunyai kesamaan dengan hasil penelian peneliti yaitu berserah diri kepada Allah SWT. dan selalu bersyukur atas apa yang didapatkannya, namun mempunyai perbedaan yaitu peneliti menggunakan seeking social support for instrumental reason yaitu menceritakan masalahnya pada orang terdekatnya dan meminta nasehatnya disaat menghadapi masalah.

Hasil penelitian Solihat (2017) yang berjudul "stress dan coping stres pada guru bantu" juga mendukung hasil penelitian peneliti dimana hasil penelitiannya yaitu samasama menggunakan strategi coping problem Focused coping dan emotional focused coping, dan menggunakan implementasi tang hampir sama yaitu dengan cara membicarakan masalahnya dengan orang yang terpercaya, melakukan aktivitas lain yang sifatnya menghibur untuk melupakan masalah yang bersifat sementara, dan yang terakhir lebih mendekatkan diri kepada Tuhan.

Hasil penelitian Septiyarani (2017), yang berjudul "Stres dan Strategi Coping Pada Petani Perempuan" yaitu stresnya ditandai dengan adanya tanda-tanda baik secara kognitif, fisiologis dan perilaku. Sedangkan strategi coping yang digunakan yaitu strategi coping problem Focused coping dan emotional focused coping. Perbedaannya terdapat pada sumber stresnya yaitu faktor ekonomi, pada petani perempuan superekonomiannya kurang dibandingkan dengan guru yang mempunyai gaji tetap.

Hasil penelitian Linayaningsih (2017), yang berjudul "strategi Coping Pada guru SLB Dalam Menghadapi anak Berkebutuhan Khusu" yaitu subjek lebih fokus mengatasi dan menghadapi masalahnya dengan menggunakan problem focused coping yang cenderung berupa keaktifan diri, perencanaan, penekanan kegiatan bersaing, kontrol diri dan 
dukungan sosial instrumental. Subjek juga menggunakan emotion focused coping yang cenderung berupa dukungan sosial emosional, interpretasi positif, penolakan dan religiusitas. Dalam jurnal ini juga mendukung hasil peneilian peneliti yang cenderung mencari dukungan social instrumental dan mendekatkan diri kepada Allah SWT. Berbagai penelitian tersebut dapat disimpulkan oleh peneliti bahwa hasil penelitian ini gambaran hasilnya sesuai dengan hasil penelitian yang dilakukan oleh peneliti sebelumnya meski subjek berbeda.

\section{SIMPULAN}

Berdasarkan hasil dari analisis strategi coping terhadap stress guru biologi yaitu, berupa stress yang dialami oleh guru berasal dari lingkungan rumah tangga dan lingkungan sekolah. Stress dari lingkungan rumah tangga bersumber dari mendidik anak, menyediakan keperluan suami dan anak, serta mendapatkan pekerjaan tambahan setelah pulang dari sekolah seperti mengurus rumah tangga. Stress dari lingkungan sekolah disebabkan karena ributnya siswa dalam ruangan saat belajar, rendahnya nilai siswa, adanya siswa yang bolos, dan kurangnya alat pembelajaran di laboratorium

Strategi coping yang dilakukan individu yaitu problem focused coping dan emotional focused coping. Pada problem focused coping individu cenderung menggunakan seeking social support for instrumental reason dalam menyelesaikan masalahnya yaitu mencari dukungan keluarga maupun orang-orang terdekatnya dengan cara menceritakan masalahnya dan meminta pendapat atau nasehat dari orang tersebut. Kemudian emotional focused coping, individu cenderung menggunakan turning to religion yaitu selalu berserah diri kepada Allah SWT, dengan berdoa agar diberi kemudahan dalam menyelesaikan masalah yang dihadapinya, agar diberi kesehatan dan selalu bersyukur atas apa yang telah didapatkannya.

Ketiga subyek sama-sama menggunakan strategi coping berupa Problem Focused Coping. Diantaranya, Mencari dukungan sosial secara instrumental (seeking social support for instrumental reason). Ketiga subyek sama-sama menggunakan strategi coping berupa emotional Focused Coping. Diantaranyakembali kepada ajaran agama (turning to religion).

\section{DAFTAR PUSTAKA}

Anoraga, P. (2006). Psikologi Kerja. Jakarta: PT Rineka Cipta.

Mahmud, D. M. (1990). Psikologi Pendidikan Suatu Pendekatan Terapan. Yogyakarta: BPFE.

Rini, J. F. (2002). Stress Kerja. Bali: Bali Usada Meditation. http://www.baliusada.com/.

Smet, B. (1994). Psikologi Kesehatan. Jakarta: Grasindo.

Sugiyono. (2014). Metode Penelitian Kuantitatif Kualitatif dan R\&D (Cet. 20). Bandung: Alfabeta.

Syah, M. (2002). Psikologi Pendidikan dengan Pendekatan Baru. Bandung: PT Remaja Rosdakarya.

Syam, M. (2002). Psikologi Pendidikan dengan Pendekatan Baru. Bandung: PT Remaja Rosdakarya. 
Wilonoyudho, S. (2001). Merenungkan Perjalanan Hidup Guru. Retrieved September 3, 2017, from http://www.kompas.com/opini/.htm

Yanti. (2013). Teknik Pemeriksaan Keabsahan Data. Retrieved September 5, 2017, from https://worddpress.com 